\title{
State of knowledge of the Chilean giant frog (Calyptocephalella gayi)
}

\section{Estado del conocimiento de la rana grande chilena (Calyptocephalella gayi)}

\author{
Marta Mora ${ }^{1, *}$, Francisca Bardi ${ }^{2} \&$ Antonieta Labra ${ }^{1,3}$ \\ ${ }^{1} \mathrm{NGO}$ Vida Nativa, Santiago, Chile. \\ ${ }^{2}$ The Nature Conservancy, Santiago, Chile. \\ ${ }^{3}$ Centre for Ecological and Evolutionary Synthesis (CEES), Department of Biosciences, University of Oslo, Norway. \\ *E-mail: marta_mora@hotmail.com
}

\begin{abstract}
Globally, at least $43 \%$ of amphibian species are declining, due primarily to habitat destruction and modification, over-exploitation, emerging diseases, and invasive alien species. In Chile there are 60 species of amphibians and of these, $62 \%$ are endemic and $73 \%$ are in a conservation category, such as the Chilean giant frog (Calyptocephalella gayi), a living fossil classified as vulnerable by the International Union for Conservation of Nature (IUCN). Its decline is associated with over-exploitation for sale of its meat as a gourmet product, together with the "megadrought" experienced by Chile in recent years, and the presence of the pathogen Batrachochytrium dendrobatidis, which is causing amphibian mortalities all over the world. The sustained increase in threats to this frog species requires strategic conservation planning, which should be based on the knowledge of aspects of their basic biology. This led us to search for the available published information on this species, compiling the reachable data on the web from 1927 to 2019. We found 353 publications, and our two main conclusions about the knowledge on this species are that there is a high percentage (43\%) of publications focused on studies of the morpho-physiological aspects, and that there is a significant lack of data on its ecology and natural history. We discuss how these deficiencies limit the possibility of implementing adequate management and/or conservation plans for this species, and finally propose areas of study that should provide a solid contribution towards the preservation of this species.
\end{abstract}

Keywords: amphibians of Chile, conservation of amphibians, living fossil.

\section{RESUMEN}

A nivel mundial, al menos el $43 \%$ de las especies de anfibios está declinando, causado principalmente por la destrucción y modificación del hábitat, sobrexplotación, enfermedades emergentes y presencia de especies exóticas invasoras. En Chile existen 60 especies de anfibios de las cuales el $62 \%$ son endémicas, y de estas, 73 \% se encuentra en alguna categoría de conservación, como es el caso de la rana grande chilena (Calyptocephalella gayi), considerada un fósil viviente y categorizada como Vulnerable (IUCN). Su declinación se asocia a la sobrexplotación por su comercialización como producto gourmet, por la "megasequía" que vive Chile en los últimos años, y por la presencia del agente patógeno Batrachochytrium dendrobatidis, causante de altas mortalidades de anfibios a nivel mundial. El incremento sostenido de las amenazas para esta especie requiere planificar estrategias para su conservación, lo cual debe sustentarse en el conocimiento existente sobre los diversos aspectos de su biología. Para establecer el conocimiento existente sobre esta especie, compilamos la información disponible de la especie en la literatura, desde 1927 a 2019. De las 353 publicaciones encontradas dos son las conclusiones fundamentales en relación al 
conocimiento de la especie: existe un alto porcentaje (43\%) de publicaciones centradas en estudios sobre la morfo-fisiología, y existe una gran falta de antecedentes de su ecología e historia natural. Discutimos cómo estas carencias limitan la posibilidad de implementar adecuados planes de manejo y/o conservación de la especie, proponiendo líneas de trabajo que permitan remediar este problema, y por lo tanto se pueda a futuro contribuir a la preservación de esta especie.

Palabras clave: anfibios de Chile, conservación de anfibios, fósil viviente.

\section{INTRODUCTION}

In the last 40 years, a significant decline of the vertebrates in general has been detected all over the world (WWF 2014), although Amphibia is the most negatively affected taxon (IUCN 2020). The main causes of this global decline are destruction and modification of habitats, pollution, introduction of exotic and invasive species, and emerging infectious diseases (Molina \& Péfaur 2010, Heatwole 2011, Bishop et al. 2012). The situation in Chile, unfortunately, follows these same trends (Díaz-Páez \& Ortiz 2003, Correa et al. 2016, Lobos et al. 2013). Currently, Chile has 60 native species of amphibians, of which 37 (62\%) are endemic and 44 (73\%) are in a conservation category (Correa 2019).

The conservation problems of the Chilean batrachofauna have motivated the development of conservation action plans, which to date have focused on six species, as follows: 1- Rhinoderma darwinii and $R$. rufum, in the "Bi-national Conservation Strategy for Darwin's Frogs", between Chile and Argentina that ends in 2028. 2- Miguel's Ground Frog (Eupsophus migueli), the Barrio's frog (Insuetophrynus acarpicus) and the Mocha Island Ground Frog (Eupsophus insularis) were included in the program "Alianza Cero Extinción" led by the Ministry of Environment, which was developed from 2016 to 2019 and involved these three species from Mehuín (Valdivia). 3- The Chilean giant frog (Calyptocephalella gayi) was the subject of the "Conservation Actions for the Chilean giant frog" project developed by the Ministry of Environment during the period 2015-2019.

The last-mentioned species, Calyptocephalella gayi (Duméril \& Bibron 1841), is considered a living fossil because it has survived almost unchanged since the Upper Cretaceous period (Agnolin 2012). It was categorized as Vulnerable by the national legislation and the IUCN, and has experienced a significant decline in the last thirty years (IUCN 2019), mainly resulting from the over-exploitation for the sale of its meat as a gourmet product (Aranguiz et al. 2007), the megadrought affecting Chile in the last five years (González et al. 2018), and emerging infectious diseases (Bacigalupe et al. 2017).

In addition to the conservation projects developed during 2015 and 2019, it is evident that more actions are needed to improve the conservation of the Chilean giant frog. To tackle any conservation program successfully, we need to have clarity about the state of knowledge on this species. Consequently, our aim is to systematize all the available information on this species. A clear idea of the state of knowledge on the Chilean giant frog will allow us to determine any progress made in the different research fields, including conservation biology. Finally, we established what we considered the most relevant biological and ecological aspects of the species, to understand what we need to study about this species and what further research and actions are necessary to promote its protection.

\section{MATERIALS AND METHODS}

We conducted a search of the available data on the Chilean giant frog in the science website Clarivate Analytics (https:// webofknowledge.com/); the SciELO online scientific bookstore (https://www.scielo.cl/); PubMed (https://www.ncbi.nlm. nih.gov/pubmed/); and Google Scholar (https://scholar. google.com/), during October 2019. We used the following keywords: Chilean frog, Chilean giant frog, helmeted water toad, Amphibians of Chile, Amphibians of the central zone, Herpetofauna of Chile, Calyptocephalella, Calyptocephalella gayi and Caudiverbera. Since the species has received different names (Muzzopappa 2020), we also included names such as Calyptocephalella caudiverbera or Caudiverbera in the search. Non-technical words were also searched in their Spanish translation. This compilation included ISI and non-ISI publications (e.g., Boletín Chileno de Herpetología, Biodiversity and Natural History, Check List), unpublished studies (e.g., technical reports, theses), books and book chapters. Scientific meeting abstracts were not included. We 
also consulted the references provided in the publications we found, in case we missed any literature.

We organized the recovered publications in a database that included the following data for each publication: title, authors, year of publication and topic. We grouped the publications in eight topics: morpho-physiology, systematics/ taxonomy, ecology, diseases, anthropology/archeology, and general information on the species (including just a report of its presence), behavior and human use. This allowed us to understand how the Chilean giant frog has been studied, and how these different lines of study have evolved.

Finally, we made a map with the distribution of the Chilean giant frog using data on locations provided by collaborators (nature observers and fauna specialist), articles and from the web.

\section{RESULTS}

We found 353 available contributions published on the web from 1927 to 2019, which include mainly documents written in English and Spanish. This database can be obtained at www. vidanativa.net. There is a continuous increase in the number of publications during this period, which is more pronounced after the 90's (Fig. 1). There is a significant bias in the effort allocated in the different topics. In fact, close to $50 \%$ of the publications involve morpho-physiological studies of the species followed by reports of its presence (Fig. 2). However, as shown in Fig. 1, morpho-physiological studies took a sharp decline after the 90's, associated with the establishment and publication of the hunting law by the Agriculture and Livestock Service (SAG 2015).

Below, we summarize the main findings on the different topics studied on this species and, in some cases, we comment on aspects that we identify as important to consider for future studies.

\section{MORPHO-PHYSIOLOGY}

An important part of the publications found in this review cover the topic of morpho-physiology ( $n=148 ; 43 \%)$, although just a small fraction of these publications (9\%) actually deal with morphology. Until the 90's, this type of studies was predominant (Fig. 1), since the species was a good model for physiological studies, because of its large size. In fact, adults can reach up to $30 \mathrm{~cm}$ of snout-vent length with a weight of $1.2 \mathrm{~kg}$ (Lobos et al. 2013). The physiological studies cover diverse subjects such as the role of the mesotocin hormone in the diuretic response (Galli-Gallardo et al. 1979), cardiac regulation (Guerrero \& Novakovic 1980), skeletal muscle activity (Cifuentes et al. 2000) and cell metabolism (Preller et al. 2007). Another subject that received significant attention was the activity of the ion channels of the olfactory epithelium (e.g., Morales et al. 1994, Bacigalupo et al. 1997). Although important progress was reached when studying the activity of these channels, this did not provide much input on aspects that could shed some light upon ecological factors that could modulate the life of this species. For this purpose, it would be useful to determine which types of food "odors" are more likely to activate these receptors, which could indicate potential food preferences, exploring for example odorants from insects and vertebrates that are part of the species diet. There was, however, one study that showed that floral and fruity odorants and putrid odors activated the $\mathrm{K}^{+}$current (Sanhueza et al. 2000). Nevertheless, it is unclear what the consequences of these observations could be in relation to habitat or food preferences. Therefore, it may be relevant to test if individuals would select or reject natural environments with certain fruit or putrid odorants.

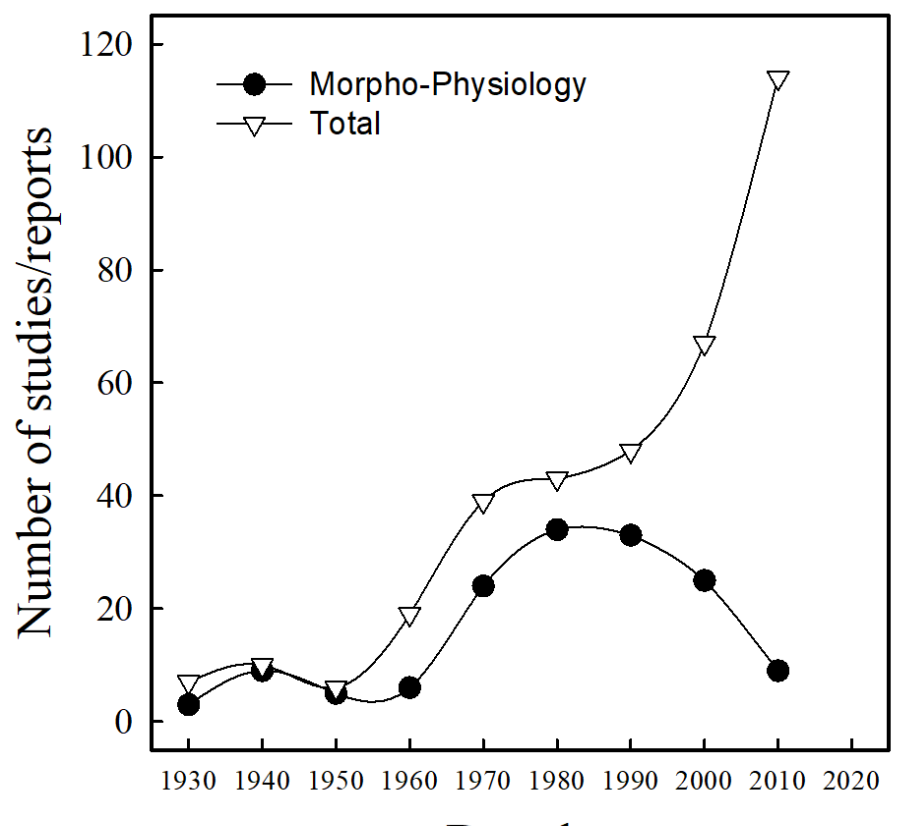

Decade

FIGURE 1. Chilean giant frog studies carried out between 1927 and 2019. This figure shows the distribution of the total studies $(n=353)$ and those of the most frequent topic, morpho-physiology $(n=148)$, across the period in decades. A high number of the studies on this topic was published during 1970-2009, showing a significant decrease after that. We included the studies found from 1927 in the 30's decade. / Estudios la de rana grande chilena realizados entre 1927 y 2019. La figura muestra la distribución del total de estudios ( $n=353$ ) y el tema más frecuente, morfofisiología ( $n=148$ ), a lo largo del período estudiado en décadas. Un gran número de estos estudios fue publicado entre 1970-2009, mostrando luego una disminución significativa. En la década de los 30's se incorporaron los estudios realizados a partir del 1927. 
This species also served as a model to study different aspects related to contamination. From these studies, we know that pentachlorophenol, a chemical used as a fungicide and/or bactericide and wood preservative, which can be found in water bodies where the species inhabits (Venegas et al. 1993), causes a permanent block of the axonal conduction and synaptic transmission (Montoya et al. 1988). Moreover, this compound also has a teratogenic effect on embryonic development (Venegas et al. 1993), and negative effects upon corneal activity (Norris \& Quevedo 1993), which may impair the visual capacity of the animal. Another chemical tested was the herbicide Chloridazon, which determines an inhibition of the bioelectric response of the adrenergic neuroepithelial synapse (Suwalsky et al. 1998). In addition, it was discovered that the insecticide Chlorpyrifos Phosphorothioate negatively affects the bioelectric activity of the skin (Suwalsky et al. 2003). In this same line, Norris \& Quevedo (1996) showed the negative effects that industrial (forestry, paper and cellulose) effluents that reached the Bio-Bío river had on

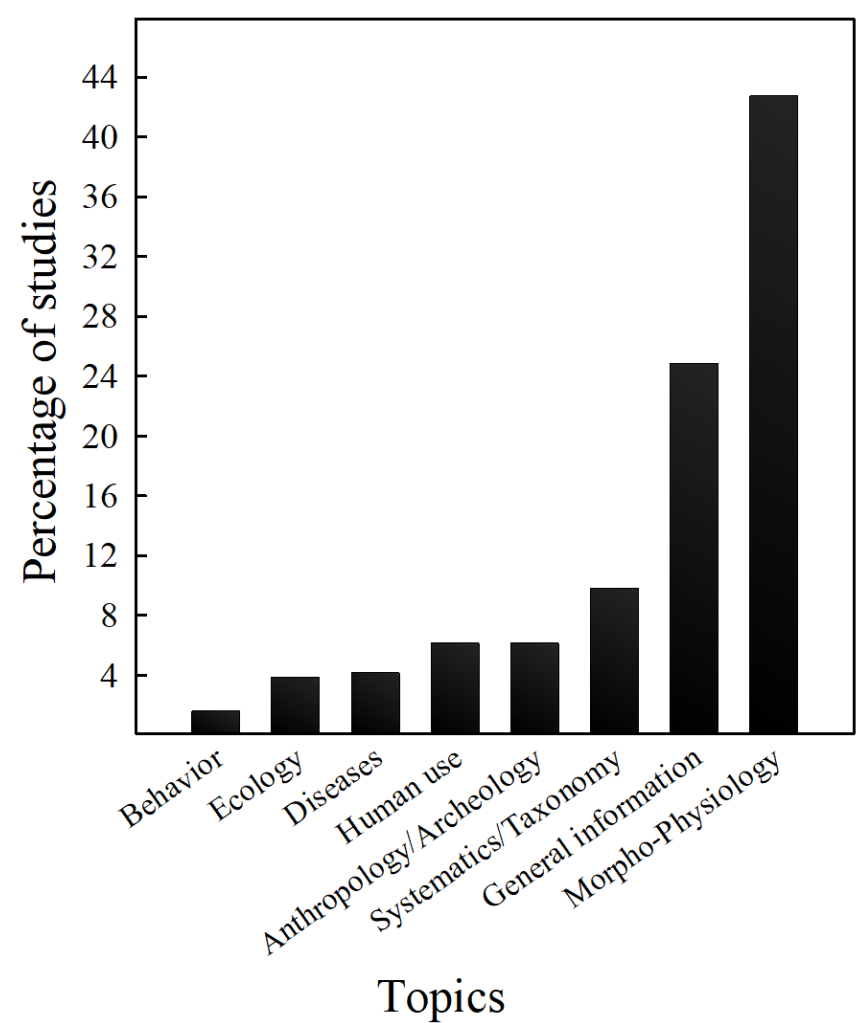

Figure 2. Percentage of studies on the Chilean giant frog by topic (behavior, ecology, diseases, human use, anthropology/ archeology, systematics/taxonomy, general information on the species and morpho-physiology). / Porcentaje de estudios de rana grande chilena por tema (conducta, ecología, enfermedades, uso humano, antropología/arqueología, sistemática/taxonomía, información general de la especie y morfo-fisiología). the skin's electrical activity. Another study showed that the presence of fluoride in the water could have negative effects on the tadpole's development and swimming behavior (Hermosilla \& Ortega 1989). All these studies show evidence of how chemical pollution disrupts different physiological and behavioral activities in the Chilean giant frog, which most probably negatively affects its wellbeing.

Morphological aspects have also been studied in tadpoles, including comparative analyses of keratinized labial teeth (Vera Candioti \& Altig 2010) and other aspects of the tadpole's oral cavity (Altig \& Johnston 1986). In relation to the reproductive system, there is currently data available on spermatogenesis (Hermosilla et al. 1983), morphology of the ovaries (Hermosilla et al. 1986) and of the Bidder organ (Wilhelm \& Lazcano de Vivaldi 1958). This latter structure is located in the testis, which produces hormones, and that can develop into ovaries under certain environmental conditions. Since there is a lack of data on the population dynamic of this species, we do not know if males can in fact develop female characters and produce eggs. Therefore, it seems interesting to study the factors that can trigger the induction of ovaries in males, ideally for a conservation program with relatively few females.

\section{SYSTEMATICS / TAXONOMY}

Recently, Muzzopappa (2020) provided a detailed analysis of how the name of this species has changed across its history, reflecting the complexity of its taxonomy and systematics. In brief, this species was described by Duméril \& Bibron (1841) as Calyptocephalus gay. Then, Myers (1962) argued that the exact name was Caudiverbera caudiverbera, but DonosoBarros (1972) proposed the use of the name Calyptocephallela caudiverbera providing arguments to show why Caudiverbera as genus was incorrect. Finally, Myers \& Stothers (2006) renamed the species as we know it today, Calyptocephalella gayi.

Across the history of this species, there have been many attempts to determine its classification, as well as to establish its phylogenetic relationships. Researchers have used different data, including hemoglobins (Bertini \& Rathe 1962), serological information (Cei 1970), and skin peptides (Cei et al. 1967). Other authors have included osteology (Lynch 1971), general morphology (Díaz \& Valencia 1985), and the morphology of the keratinized teeth of the tadpoles (Vera Candioti \& Altig 2010). Currently, genetic tools are providing a better understanding of the phylogenetic relationships of the Chilean giant frog (Irisarri et al. 2012, Streicher et al. 2018), boosting interest in the systematics of this species, which has remained an active field of research.

Phylogenetic studies with data from extant species (Pyron 
\& Wiens 2011, Pratihar et al. 2017) and fossil data (Pyron 2011), have helped to understand the evolution of $C$. gayi. However, the studies of the fossil species Calyptocephalella canqueli have been particularly relevant to understand the evolution of this genus (Muzzopappa \& Báez 2009, Muzzopappa \& Nicoli 2010), helping to clarify the reason why this species is called a living fossil. The Chilean giant frog is the only survivor in the taxon, and all sister species are only known from fossil records. In addition, $C$. gayi had remained basically unchanged since the extinction of other species in this taxon (Otero 2014).

\section{ECoLoGY}

The Chilean giant frog inhabits from sea level up to around $1200-1286 \mathrm{~m}$ asl (Horta et al. 2018, Charrier 2019). It has aquatic habits and can be found in water bodies such as lagoons, streams, wetlands, estuaries and ponds (Rabanal \& Núñez 2008). The highest population density is found between Cauquenes and Valdivia, in areas with lentic waters (Mujica 2009, for more information see "General information on the species").

Cei (1962) described this species as a voracious amphibian that feeds on fishes, insect larvae, crustaceans, birds, and small mammals. In addition, adults can exhibit intraguild predation, consuming other amphibians such as the African frog (Mora et al. 2016). Moreover, the largest individuals can be cannibals, and predate upon individuals of their own species (Acuña et al. 2014). It was also stated that individuals can survive four months without feeding, and females can lay eggs normally even if they have not eaten (Schneider 1930).

Under natural conditions, tadpoles consume detritus from animal or plant origin (Acuña et al. 2014). However, under laboratory settings, one survival strategy of the tadpoles is to grow at different speeds so that the co-occurrence of different metamorphic stages makes it possible for juveniles to feed on the smaller siblings (Vélez 2014).

Very little is known about the predators of this frog, and presently, it is only known that adults are consumed by the mammal huillín, Lontra provocax (González 2006, Franco et al. 2013), the bird Martín pescador, Megaceryle torquata (Enrique Ziehlmann pers. comm.), and that tadpoles are predated by the African frog, Xenopus laevis (Fibla et al. 2020).

From 2010, the central zone of Chile has been affected by a megadrought (González et al. 2018), causing collapses of the freshwater ecosystems (Alaniz et al. 2019). A case that illustrates the effect of the megadrought on the Chilean giant frog was a field trip in January of 2013 to the Matanza lagoon (El Yali wetland). Mizobe et al. (2014) found 162 carcasses and later in February of 2014 they found 86 new carcasses, embedded in a completely dry substrate, under high temperatures. This was attributed to the abrupt change in the physical conditions of the environment occupied by the species, specifically the lack of water (Acuña et al. 2014).

\section{DISEASES}

The Chilean giant frog has been bred in captivity and it also been widely used for research purposes (Forzán et al. 2017), which has enabled the study of diverse parasites of this species. The first parasite to be studied was a small intestinal cestoda called Ophiotaenia noei (Wolffhügel, 1948). Following this, the digenic Gorgoderina trematode was found in the urinary bladders of a population in Valdivia (Puga 1979). Subsequently, a study carried out in a center for frog reproduction, where tadpoles and juveniles were sacrificed, allowed to detect the presence of three gastrointestinal parasites, Balantidium sp., Entamoeba sp. and Hexamita sp. (López et al. 2014). In addition, a histopathological study showed the presence of Mycobaterium sp. in 60 postmetamorphics that had granulomatous inflammation in the head, extremities and internal organs (Vélez \& Acuña 2012).

Finally, two pathogens have been found in this species associated with emerging diseases and the presence of the African frog (Xenopus laevis), Ranavirus and Batrachochytrium dendrobatidis (Soto-Azat et al. 2016). The first is the virus of the Ranavirus genus, which causes massive frog mortalities around the world, provoking pathognomonic lesions such as skin ulcerations and hemorrhagic syndrome (Teacher et al. 2010). In Chile, the presence of Ranavirus was first detected in wild African frogs without symptoms of the disease, and in one bred individual of the Chilean giant frog (Soto-Azat et al. 2016). The second pathogen is $B$. dendrobatidis (Bd), a fungus that causes the disease called chytridiomycosis identified as responsible for high amphibian mortality around the world, with no obvious symptoms (Berger et al. 1998). Bd is a zoospore that infects keratinizing squamous epithelial cells (Berger et al. 1999) generating hyperplasia and hyperkeratosis (Voyles et al. 2009). Typical clinical signs are lethargy, lack of appetite, cutaneous erythema, irregular skin sloughing, abnormal posture (hind legs abducted), and loss of righting reflex (Voyles et al. 2009). In Chile, this pathogen has been registered in different anuran species (Correa et al. 2016, Soto-Azat et al. 2016, Bacigalupe et al. 2017). Bacigalupe et al. (2017) sampled and analyzed 24 species and found that the most infected species were Pleurodema thaul, $X$. laevis and C. gayi. The relationship established between the presence of the African frog and the presence of these two emerging diseases in native anurans is worrisome, because these are a well-known threat to the survival of amphibians (Soto-Azat et al. 2016), and hence, for the Chilean giant frog. 


\section{Anthropology / ARCHEOLogy}

The Chilean giant frog was highly relevant for different Pre-Colombian societies throughout history. For example, in central Chile close to the old Tagua Tagua lagoon, in Cuchipuy, there is evidence that humans inhabited the area during the Pleistocene and also this frog species, which was found in skeletal fossil remains (Arenas et al. 2016). Similarly, in the Bio-Bío Region, on the Hualpén peninsula, archeofaunistic remains were found and one of the most abundant species was the Chilean giant frog (Bahamondes et al. 2006). Furthermore, with the analysis of stable isotopes carried out on remains of human bones and teeth, this frog was identified as part of the diet of the pottery cultures in central Chile (Falabella et al. 2007, Tykot et al. 2009). Other evidence indicates that human populations established near water bodies, in the Araucanía Region, consumed this frog species (Quiroz \& Martínez 2012).

The relevance that the Chilean giant frog had in the pre-Columbian societies is also reflected by the fact that in the Mapuche ethnozoology this species has its own name, "pakarwa" (Villagrán et al. 1999).

\section{GENERAL INFORMATION ON THE SPECIES}

There are 88 publications that mention the presence of the species in Chile (e.g., Barerra 2011, Barraza 2017), but in most cases, the reports are only based on literature review and hence do not make any new contributions on this species. Other publications have focused on the distributional range of this species. Cei (1962) described the distribution of this frog between Coquimbo and Los Lagos Regions. Recently, the presence of the species was recorded in the Atacama Region (Charrier 2019, Mella \& Horta 2019), and in the south, in the Aysén Region (Rabanal \& Núñez 2008, Charrier 2019) and in Protected Areas, such as El Yali National Reserve and Río de Los Cipreses National Reserve (Fig. 3; Brito 1999, Horta et al. 2014). We retrieved information on the species distribution from collaborators and from internet (data available at www. vidanativa.net), which shows that there are records in areas where the IUCN (2019) indicates that the species is potentially extinct. The mismatch between these data demonstrates the need for better surveys to clarify the current distribution of the species, including its presence in the Aysén Region.

In the last 10 years, four field guides of the amphibians present in Chile were carried out (Rabanal \& Núñez 2008, Celis-Diez et al. 2010, Charrier 2019, Garín \& Hussein 2013), which constitute an essential contribution to the knowledge, conservation and valuation of the species.

The concern for this species has triggered two conservation initiatives in the Metropolitan Region. The first initiative, the "Conservation actions for the Chilean giant frog (Calyptocephalella gayi)" program (Carrasco et al. 2016), produced list of actions to enhance species conservation.

The second initiative was developed during 2018-2019, the "Batuco Conservation Action Plan" to be carried out during 2018 - 2023 in Batuco wetland, where this frog species is considered a conservation target (TNC 2019). This action plan, currently under implementation, will be very important because it will allow the development of studies focused on habitat restoration and elimination of threats (e.g., Xenopus laevis) for the Chilean giant frog. In addition, the program will allow us to gain better knowledge of the condition of a population that inhabits one of the regions in Chile most affected by anthropic perturbations (Romero et al. 2007).

An interesting study performed at the Peñuelas National Reserve explored the value that people give to biodiversity attributes and water supply, in which this frog species was included (Cerda 2013). Using surveys, visitors were asked for their willingness to pay for four attributes related to maintenance of a good equilibrium for the environment and the visitors of the park. The points were: chances of observing different animals in a visit, availability of drinkable water, existence of endemic orchids and existence of an endemic amphibian (C. gayi). This study concluded that people were willing to support economically and hence, to promote, research on this species. The visitors argued that this endemic frog has the right to remain in the system, not just because the species is important for science and for the functioning of ecosystems, but also, because frogs are attractive to children (Cerda 2013). These results are telling us that the citizens want to help to preserve the environment, and therefore, more actions should be developed with more citizen participation.

The concern expressed by these visitors may partially be associated with the different conservation actions taken by private organizations. We can mention at least two organizations that are actively working for the conservation of Chilean amphibians, with special emphasis in the Chilean giant frog: "Salva a tu rana C. gayi" and "NGO Vida Nativa". These organizations have carried out outreach activities to improve knowledge on this species and amphibians in general. Other important organizations are those that promote information sharing on local fauna, and making it available to everybody, such as "Batracios de Chile" on Facebook, and the project "Herpetomaps" on iNaturalist.

\section{BEHAVIOR}

The aggressive display of this species is triggered when individuals, adults or juveniles, are threatened and/or caught. Frogs respond inflating their lungs, and also their bodies, and 
in some cases their flanks vibrate, a unique behavior among the Chilean native anurans. During the aggression, individuals always keep the mouth widely open emitting aggressive calls (Fig. 4), as was described by Donoso-Barros (1972) and Veloso (1977).

This species also emits advertisement calls, which are produced by males during the breeding season (between September and February) to attract females (Cei 1962). Males call at the edge of the water bodies, partially submerged (Penna \& Veloso 1990). These vocalizations have low tones, with repeated intervals of short duration (Cei 1962), which were described by Penna \& Veloso (1990).
A different behavioral aspect studied in tadpoles under laboratory settings, is their response to chemical stimuli from an exotic predator, the fish Australoheros facetus (Alzamora 2014). The author showed that this predator heavily consumes $C$. gayi, and that tadpoles did not recognize the chemical cues of this predator. Although it can be expected that $C$. gayi tadpoles did not recognize the exotic predator, these results indicate that under natural conditions, the early stages of $C$. gayi may suffer a high predation, which imposes an extra threat to this species with conservation problems. Therefore, it seems necessary to control the populations of the Australoheros facetus.
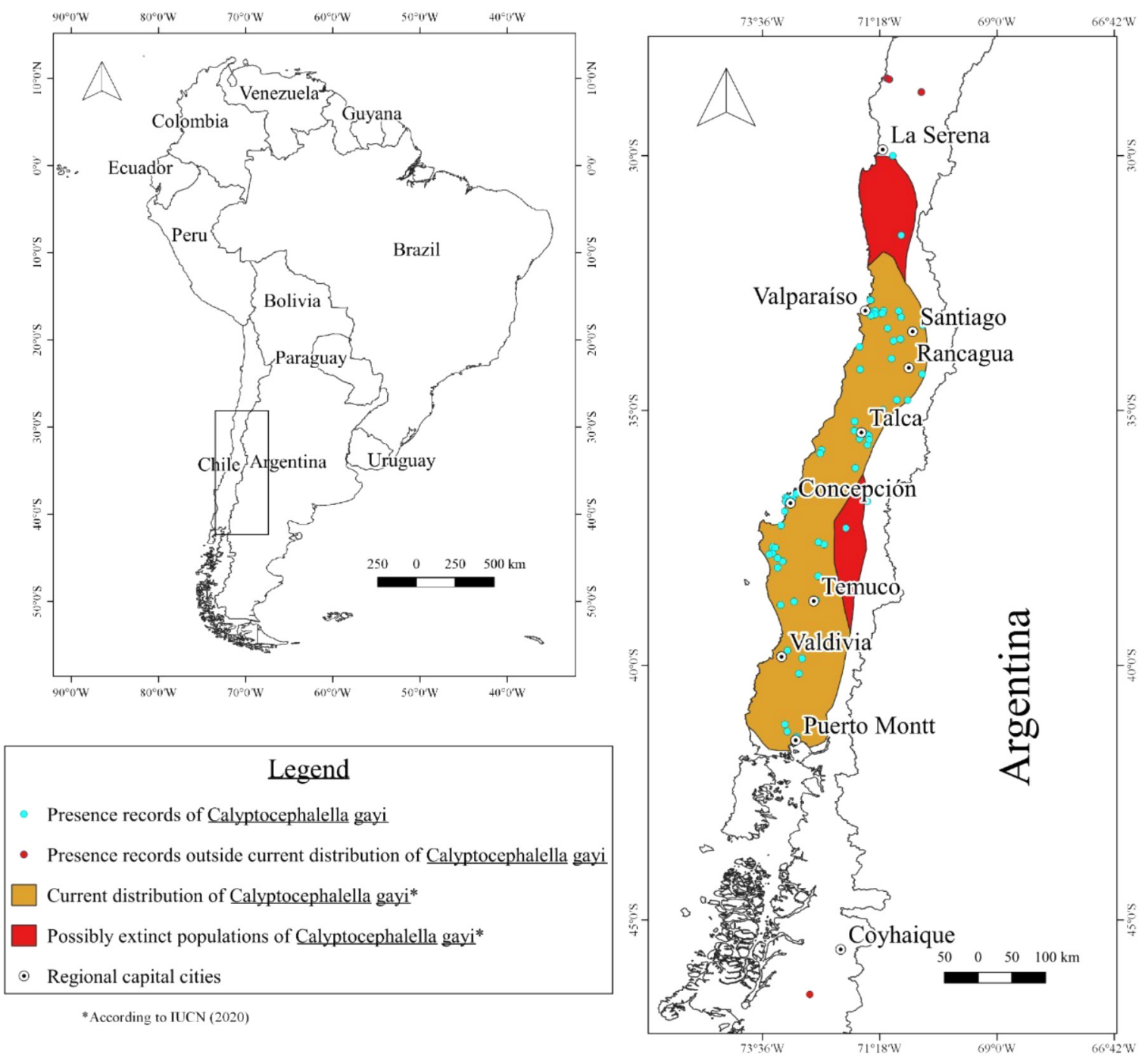

FIgURE 3. Map showing the estimated distribution range of Calyptocephalella gayi in Chile. For details, see Supplementary material available at https://www.vidanativa.net/ (Table S1, Localities in Chile with records of C. gayi). / Mapa del rango de distribución de Calyptocephalella gayi en Chile. Para más detalles, ver el material suplementario disponible en https://www.vidanativa.net/ (Tabla S1, Localidades en Chile con registros de C. gayi). 


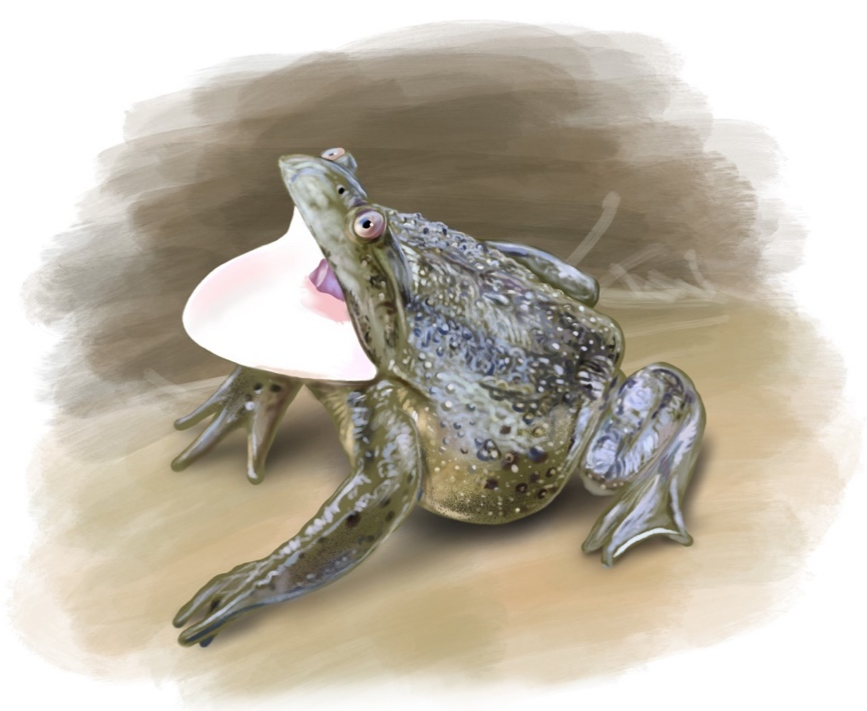

FIgURE 4. Aggressive position of the Chilean giant frog when threatened. Illustration made by R. Verdugo. / Posición agresiva de la rana grande chilena cuando se ve amenazada. Ilustración hecha por R. Verdugo.

\section{HUMAN USE}

Historically, humans have used the Chilean giant frog for different purposes: for medicinal uses (Alves et al. 2013), for the sale of its meat (Aránguiz et al. 2007), as a biological model for research (Lobos et al. 2013) and for teaching (IbarraVidal 1989, Hermosilla \& Acuña 2004). The human use, unfortunately, has involved an overexploitation of the species, particularly for consumption, but also as an exotic pet (Ortiz 1988). This commercial value motivated the development of the frog farming during the 70's, even though there was a significant lack of knowledge on the basic biology of this species, i.e., ecology and behavior (Hermosilla \& Acuña 2004). In 1975, Chilean farms were producing between 10 to 15 tons of Chilean giant frog legs to be marketed in restaurants and food stores (Vietmeyer 1980). Furthermore, during the 90's, a study concluded that the frog market was expanding and that approximately 100,000 individuals were sold (Taibo 2000). Frog farmers, however, produced knowledge on the species, particularly on the effects of the different types of diets on tadpole growth. In addition, farmers contributed with information on the necessary care and infrastructure to achieve a successful captivity-breeding program, such as aspects of the heating system for tadpoles (Acuña 1996, Taibo 2000, Hermosilla \& Acuña 2001, Ortiz 2002, Toledo et al. 2014). Thereafter, Vélez (2014) made an extensive compilation of the information available from frog farmers, which included aspects on the infrastructure to maintain the individuals, and data on nutritional, physiological and reproductive aspects of this species in captivity. Her book "Manejo en cautiverio de la rana grande chilena Calyptocephalella gayi (Duméril y Bibron 1841)" is nowadays the main referent for carrying out conservation and management plans for this species.

In 2006, the Food and Agriculture Organization of the United Nations (FAO) requested from its members a report of the situation of the zoogenetic resources of their countries (Mujica 2006), understanding as a zoogenetic resource "animals with economical potential, scientific use or of cultural interest that are used, or can be used, in population food production" (Weiner 1989). This frog species was considered one of these products, and remarkably, it was evaluated as a little used resource (Mujica 2006).

The decrease of the Chilean giant frog population is concerning (IUCN 2018), and what is even more worrisome is that only adults, and not intermediate stages, are found in the farms, which suggests that animals are most likely being taken from their natural environment (Lobos et al. 2013). Currently, there are five frogs farms in the following Chilean regions: one in Valparaíso, one in Nuble region, two in El Maule and one in Metropolitan (Marcela Alcaide, pers. comm.). This also indicates that it is necessary to ensure traceability of the specimens that are being marketed, considering that, the price of this frog is striking, reaching a value of $\$ 15,000$ per frog in 2000 (Taibo 2000).

\section{DISCUSSION}

The Chilean giant frog has been a subject of research and interest for almost 100 years. We found 353 publications, and the main topic tackled was the morpho-physiology of the species, although the scientific production in this topic started to drop dramatically after the 90's, when the government promoted the protection of the native fauna. The third topic more frequently addressed, after the topic "General information on the species" (i.e., species presence), was systematics/taxonomy, and in fact, recently a summary of all scientific names that the Chilean giant frog has received was published (Muzzopappa 2020), which shows the complexity of the evolutionary relationships of this living fossil. On the other hand, it is evident that our present knowledge on the behavior and ecology of this frog is very scarce, which are topics that need more research in order to propose conservation programs sustained by a strong knowledge of the species.

Although it can be considered that there is a wide scope and varied information on the species, there are some data that unfortunately are not possible to find in the literature 
or in reliable internet sources, which are very important for the conservation of this species. For example, when a project (e.g., energy, mining) is evaluated by the Environmental Assessment Service ("Servicio de Evaluación Ambiental", SEA), and the presence of low mobility animals like this frog is detected in the area of the project, the law requests that actions should be taken such as rescue and relocation (SAG 2014). However, it is necessary to have access to adequate microhabitats to implement these actions, where it can be possible to release the individuals. This is usually not possible. In addition, until our extensive search for geographic records, we had much less clarity about the distribution of this species. We also lack data on basic aspects of the biology of this species, such as its diet under natural conditions. Thus, if we were to release individuals and if the species has a preferred food, would it face problems in finding their preferred food? Aspects such as this, added to the total lack of population data such as size, density, and dynamics, or their home ranges, reduce significantly our possibilities to properly implement in-situ conservation programs. In addition, even if ex-situ conservation programs are developed, are we prepared to restock areas where this frog was present in the past?

Most amphibian populations naturally experience important fluctuations, mainly due to the environmental stochasticity (Molina \& Péfaur 2010), and therefore, it is necessary to follow populations for many years and monitor them for either a medium (from one to five years) or a longterm (more than five years) period. This would allow us to obtain enough ecological data to predict the response of the species to natural and/or anthropogenic perturbations.

Another important aspect necessary to tackle is related to one of the main threats to this species: its overexploitation for consumption. An example of this is that in June of 2017, the Agriculture and Livestock Service found 15 wild frogs in the Arauco province that were going to be cooked in a restaurant (https://www.biobiochile.cl/noticias/nacional/ region-del-bio-bio/2017/06/14/incautan-15-ranas-enpeligro-de-extincion-que-iban-a-ser-cocinadas-en-local-delaraquete.shtml).

There are, however, other threats that require urgent study, such as the direct and indirect impact of invasive alien species such as Xenopus laevis, Australoheros facetus, Gambusia holbrooki, can have on this frog species, since it is increasingly common to find these alien species in natural conditions in different Chilean water bodies (Jaksić \& Castro 2014). Only two studies have focused on the direct effects of these alien species upon this frog. One is the predation upon larvae under experimental laboratory conditions by Australoheros facetus, an invasive fish (Alzamora 2014). The other is the transmission of diseases by chytridiomycosis and ranavirus by $X$. laevis, both declared responsible in many countries for the decline of amphibians (Soto-Azat et al. 2016, Bacigalupe et al. 2017). Both studies are telling us that the Chilean giant frog is threatened by invasive species and emerging diseases, which is added to a number of widely recognized threats to amphibians such as overexploitation, water contamination, loss and fragmentation of the habitat (Lobos et al. 2017).

We conclude that it is necessary to implement urgently measures to protect the Chilean giant frog by conducting studies in wildlife and protecting its habitats, which must be complemented with environmental education. In each of the topics discussed we have proposed specific aspects that need further research, although the list of unknown aspects of this frog is, unfortunately, much longer. This highlights the urgent need to implement research on the basic characteristics of this frog. We hope that the present review motivates organizations and institutions to allocate resources to ensure the maintenance of the Chilean giant frog in its natural environment. Finally, we would like to thank to all those private organizations that are fighting to protect and save not only this living fossil, but also the different ecosystems of this country where amphibians still survive.

\section{ACKNOWLEDGEMENTS}

The authors thank the project "Estudio de rana chilena (Calyptocephalella gayi) en Batuco, Region Metropolitana" from The Nature Conservancy and NGO Vida Nativa that funded this study. We also thank the following people: Marcela Alcaide (Servicio Agricola y Ganadero) for the valuable information on Chilean frog farms; Rodrigo Verdugo for the illustrations; Juan Contardo for making the map showing the distribution of the Chilean giant frog; Enrique Ziehlmann for sharing unpublished information on the Chilean giant frog; and Felipe Suazo for his advice on anthropological/archeological issues. In addition, the authors thank the important contributions made by an anonymous reviewer. Finally, we grateful to all those who contributed disinterestedly with records to elaborate the distribution map of the Chilean giant frog (Andrés Charrier, Daniel Keufumanke, Harold Gillibrand, Michael Weymann, Mauricio Ayala, Felipe Rabanal, Alejandro Eid, Tamara Martínez, Cristian Cuevas, Juan Contardo, Bernardo Segura, Consuelo Martín Peigneguy, Inao Vásquez, Jose Diego Rodríguez, Pablo Fuentes, Karlos Krumm Kenrick, Viktor Franky Alvarado, Mi Kulliñ, Bruno Savelli, Daniel Salinas), and in special to Edgardo Flores. 


\section{REFERENCES}

Acuña, P., Vélez, C., Mizobe, C., Bustos-López, C., ContrerasLópez, M. 2014. Mortalidad de la población de rana grande chilena, Calyptocephalella gayi (Calyptocephalellidae), en la laguna Matanzas, del humedal El Yali. Anales del Museo de Historia Natural de Valparaíso 27: 35-50.

Agnolin, F.L. 2012. Una nueva Calyptocephalellidae (Anura, Neobatrachia) del Cretácico Superior de la Patagonia, Argentina, con comentarios sobre su posición sistemática. Studia Geologica Salmanticensia 48: 129-178.

Altig, R., Johnston, G.F. 1986. Major characteristics of free-living anuran tadpoles. Smithsonian Herpetological Information Service 1-75. https://doi.org/10.5479/si.23317515.67.1

Alves, R.N., Vieira, W.L., Santana, G.G., Vieira, K.S., Montenegro, P.F. 2013. Herpetofauna used in traditional folk medicine: conservation implications. In: Alves, R., Rosa, I. (Eds.) Animals in traditional folk medicine: 109-133. Springer, Berlin, Heidelberg.

Alzamora, A. 2014. Depredación de larvas de anfibios por peces exóticos y evaluación de la detección de señales químicas como mecanismo de defensa en Chile central. Master thesis. Universidad de Chile, Santiago, Chile.

Aránguiz, A., Lagos, F., Leiva, A., Rojas, P., Soto, M. 2007. Situación actual y expectativas de la producción de carnes exóticas en Chile. Undergraduate thesis. Universidad de Concepción, Chillán, Chile.

Arenas, P., Jara, J., Bastías, J., Jackson, D. 2016. Nuevos datos en torno a la ocupación alfarera de Cuchipuy, Chile central. Boletín de la Sociedad Chilena de Arqueología 46: 7-22.

Bacigalupe, L.D., Soto-Azat, C., García-Vera, C., Barría-Oyarzo, I., Rezende, E.L. 2017. Effects of amphibian phylogeny, climate and human impact on the occurrence of the amphibian-killing chytrid fungus. Global Change Biology 23: 3543-3553.

Bacigalupo, J., Morales, B., Labarca, P., Ugarte, G., Madrid, R. 1997. Inhibitory responses to odorants in vertebrate olfactory neurons. In: Latorre, R., Saez, C. (Eds.) Ion channels to cellto-cell conversations: 269-284. New York: Plenum Press.

Barerra, S. 2011. Análisis del nivel hídrico y las condiciones del humedal de la Laguna de Batuco. Undergraduate thesis. Universidad de Chile, Santiago, Chile.

Barraza, J.E. 2017. Modelo de integración para el mejoramiento de la convivencia entre el estado de Chile, las comunidades locales y el bosque nativo. Caso de estudio de la comuna de Alhué, Región Metropolitana, Chile. Master thesis. Universidad de Chile, Santiago, Chile.

Berger, L., Speare, R., Daszak, P., Green, E., Cunningham, A., Goggin, L., Slocombe, R., Ragan, M., Hyatt, A., McDonald, K., Hines, B., Lips, K., Marantelli, G., Parkes, H. 1998.
Chytridiomycosis causes amphibian mortality associated with population declines in the rain forests of Australia and Central America. Proceedings of the National Academy of Sciences of the United States of America 95: 9031-9036.

Bishop, P.J., Angulo, A., Lewis, J.P., Moore, R.D., Raab, G.B., Moreno, G. 2012. The Amphibian Extinction Crisis what will it take to put the action into the Amphibian Conservation Action Plan? Surveys and Perspectives Integrating Environment and Society 5: 97-111.

Brito, J.L. 1999. Vertebrados del humedal La Reserva Nacional El Yali y su costa, Santo Domingo, Chile central. Anales del Museo de Historia Natural de Valparaíso 24: 121-126.

Carrasco-Lagos, P., Moreno, R. A., Tala, C., Ibarra-Vidal, H., Duarte, M.2016. Vertebrados En Peligro de la Región Metropolitana de Santiago, Chile. Editions Seremi del Medio Ambiente Región Metropolitana de Santiago, Universidad Santo Tomás, Ministerio del Medio Ambiente, Ediciones al Conocimiento, Instituto de Ecología y Biodiversidad (IEB-Chile) and Minera Florida, Chile. 52 pp.

Cei, J.M. 1962. Batracios de Chile. Editions Universidad de Chile, Santiago, Chile. 240 pp.

Celis-Diez, L., Ippi, S., Charrier, A., Garín, C. 2011. Fauna de los bosques templados de Chile. Corporación Chilena de la Madera, Concepción, Chile. 260 pp.

Cerda, C. 2013. Valuing biodiversity attributes and water supply using choice experiments: a case study of La Campana Peñuelas Biosphere Reserve, Chile. Environmental Monitoring and Assessment 185: 253-266.

Cifuentes, F., Vergara, J., Hidalgo, C. 2000. Sodium/calcium exchange in amphibian skeletal muscle fibers and isolated transverse tubules. American Journal of Physiology-Cell Physiology 279: C89-C97.

Charrier, A. 2019. Anfibios de los bosques de la zona centro sur y Patagonia de Chile. Editions Corporación Chilena de la Madera, Santiago. 297 pp.

Correa, C., Donoso, J.P., Ortiz, J.C. 2016. Estado de conocimiento y conservación de los anfibios de Chile: una síntesis de los últimos 10 años de investigación. Gayana 80: 103-124.

Correa, C. 2019. Nueva lista comentada de los anfibios de Chile (Amphibia, Anura). Boletín Chileno de Herpetología 6: 1-14.

Díaz-Páez, H., Ortiz, J.C. 2003. Evaluación del estado de conservación de los anfibios en Chile. Revista Chilena de Historia Natural 76: 509-525.

Donoso-Barros, R. 1972. Datos adicionales y comportamiento agresivo de Calyptocephalella caudiverbera (Linnaeus). Boletín de la Sociedad de Biología de Concepción 45:95103.

Falabella, F., Planella, M.T., Aspillaga, E., Sanhueza, L., Tykot, R.H. 
2007. Dieta en sociedades alfareras de Chile central: aporte de análisis de isótopos estables. Revista de Antropología Chilena 39: 5-27.

Fibla, P., Serrano, J.M., Cruz-Jofré, F., Fabres, A., Ramírez, F., Sáez, P., Otalora, K., Méndez, M.A. 2020. Evidence of predation on the Helmeted water toad Calyptocephalella gayi (Duméril \& Bibron, 1841) by the invasive African clawed frog Xenopus laevis (Daudin 1802). Gayana 84: 56-59.

Forzán, M.J., Jones, K.M., Ariel, E., Whittington, R.J., Wood, J., Frederick Markham, R.J., Daoust, P.Y. 2017. Pathogenesis of frog virus 3 (Ranavirus, Iridoviridae) infection in wood frogs (Rana sylvatica). Veterinary Pathology 54: 531-548.

Franco, M., Guevara, G., Correa, L., Soto-Gamboa, M. 2013. Trophic interactions of the endangered Southern river otter (Lontra provocax) in a Chilean Ramsar wetland inferred from prey sampling, fecal analysis, and stable isotopes. Naturwissenschaften 100: 299-310.

Galli-Gallardo, S.M., Pang P.K.T., Oguro. C. 1979. Renal responses of the Chilean toad, Calyptocephalela caudiverbera, and the mud puppy, Necturus maculosus, to mesotocin. General and Comparative Endocrinology 37: 134-136.

Garín, C., Hussein, Y. 2013. Guía de reconocimiento de anfibios y reptiles de la Región de Valparaíso. Editions Servicio Agrícola y Ganadero, Santiago. 63 pp.

González, C. 2006. Dieta del huillín (Lontra provocax) en el humedal de Boroa, IX región, Chile. Undergraduate thesis. Universidad Austral de Chile, Valdivia, Chile.

González, M.E., Gómez-González, S., Lara, A., Garreaud, R., DíazHormazábal, I. 2018. The 2010-2015 Megadrought and its influence on the fire regime in central and south-central Chile. Ecosphere 9: e02300. doi:10.1002/ecs2.2300

Guerrero, S., Novakovic, L. 1980. Effects of 4-aminopyridine on pacemaker activity of frog sinus venosus. European Journal of Pharmacology 62: 335-340.

Heatwole, H. 2013. Worldwide decline and extinction of amphibians. In: Rohde, K. (Ed.)The balance of nature and human impact: 259-278. Cambridge University Press: Cambridge.

Hermosilla, I., Urbina, A., Cabrera, J.C. 1983. Espermatogénesis en la rana chilena Caudiverbera caudiverbera (Linne, 1758) (Anura, Leptodactylidae). Boletín de la Sociedad de Biología de Concepción 54: 103-115.

Hermosilla, I., Coloma, L., Weigerth, G., Reyes, E., Gómez, V. 1986. Caracterización del ovario de la rana chilena Caudiverbera caudiverbera (Linne, 1758) (Anura Leptodactylidae) Boletín de la Sociedad de Biología de Concepción 57: 37 47.

Hermosilla, I., Ortega, J.C. 1989. Efecto del fluor en el desarrollo embrionario del anuro chileno Caudiverbera caudiverbera: crecimiento y capacidad de natación. Boletín de la
Sociedad de Biología de Concepción 60: 129-137.

Hermosilla, I., Acuña, P.L. 2004. Crianza en cautividad de la rana grande chilena (Caudiverbera caudiverbera) (Linnaeus, 1758). In: Iriarte, A., Tala, C., González, B., Zapata, B., González, G., Maino, M. (Eds.) Cría en cautividad de fauna chilena: 105-122. Servicio Agrícola y Ganadero, Santiago, Chile.

Horta-Pizarro, I., Soffia, M.F., Mora, M., Aguilar, A., Lobos, P., Valdovinos, C. 2014. Antecedentes preliminares del estudio de la batracofauna en la Reserva Nacional Río de Los Cipreses y el Alto Cachapoal, Región del Libertador Bernardo O'Higgins. Biodiversidata 2: 117-119.

Horta-Pizarro, I., Soffia, F., Valle-Codina, T. 2018. Antecedentes sobre la presencia de Calyptocephalella gayi (Duméril y Bibron 1841) (Amphibia, Anura, Calyptocephallidae) en la cuenca del Alto Cachapoal, Región de O'Higgins. Boletín Chileno de Herpetología 5: 12-15.

Ibarra-Vidal, H. 1989. Impactos de las actividades humanas sobre la herpetofauna en Chile. Museo Regional de Concepción 3: 33-39.

Jaksić, F.M., Castro, S.A. 2014. Invasiones biológicas en Chile, causas globales e impactos locales. Ediciones Universidad Católica de Chile, Santiago. 526 pp.

Lobos, G., Vidal, M., Correa, C., Labra, A., Díaz-Páez, H., Charrier, A., Rabanal, F., Díaz, S., Tala, C. 2013. Anfibios de Chile, un desafío para la conservación. Editions Ministerio del Medio Ambiente. 104 pp.

López, O., Acuña, P., Rodríguez, J., Vélez-R, C. 2014. Enfermedades infecciosas emergentes y parásitos. In: Vélez, C.M. (Eds.) Manejo en cautiverio de la rana grande chilena, Calyptocephalella gayi (Duméril y Bibron 1841): 93-112. Universidad Santo Tomás, Santiago, Chile.

Mella, J., Horta, I. 2019. Ampliación de la distribución geográfica de la rana grande chilena Calyptocephalella gayi (Dúmeril \& Bibron 1841) (Anura, Calyptocephalellidae): registros en la Región de Atacama, Chile. Boletín Chileno de Herpetología 6: 5-18.

Mizobe, C., Contreras-López, M., Acuña-O, P., Vélez, C, Vélez, R., Bustos-López, C. 2014. Mortalidad masiva de la rana grande chilena (Calyptocephalella gayi) en la Reserva Nacional El Yali. Biodiversidata 2: 30-34.

Molina, C., Péfaur, J. 2010. Declinación de poblaciones de anfibios: Una revisión bibliográfica comentada (1960 -2000). Revista de Ecología Latino Américana 15: 31-46.

Montoya, G.A., Roa, J., Cruz, F., Villena, F., Pezo, P. 1988. The actions of phenol and pentachlorophenol (PCP) on axonal conduction, ganglionic synaptic transmission, and the effect of $\mathrm{pH}$ changes. Comparative Biochemistry and Physiology Part C: Comparative Pharmacology 89: $377-$ 382. 
Mora, M., Constanzo-Chávez, J., Contardo, J, Labra, A. 2016. First report of predation by Calyptocephalella gayi upon the invasive species Xenopus laevis (Amphibia, Anura, Calyptocephalellidae and Pipidae). Herpetology Notes 9: 171-173.

Morales, B., Ugarte, G., Labarca, P., Bacigalupo, J. 1994. Inhibitory $\mathrm{K}+$ current activated by odorants in toad olfactory neurons. Proceedings of the Royal Society of London. Series B: Biological Sciences 257: 235-242.

Mujica, F. 2006. Diversidad, conservación y utilización de los recursos genéticos animales en Chile. Boletín INIA 137. Osorno, Ministerio de Agricultura de Chile, Instituto de Investigaciones Agropecuarias. 124 pp.

Mujica, F. 2009. Diversity and conservation of Chilean zoogenetic resources. Agro Sur 37: 134-175.

Muzzopappa, P. 2020. Historias de lagartos y ranas la salamandra aquatique et noire de Feuillé (1714). Historia Natural 10: 107-115.

Myers, G. 1962. The American Leptodactylid Frog genera Eleutherodactylus, Hylodes (= Elosia), and Caudiverbera (= Calyptocephalus). Copeia 1962: 195-202.

Myers, G., Stothers, R. 2006. The myth of Hylas revisited: the frog name Hyla and other commentary on specimen medicum (1768) of J. N. Laurenti, the "father of herpetology". Archives of Natural History 33: 241-266.

Norris, B., Quevedo, L. 1993. Pentachlorophenol (PCP) inhibits ion transport in the isolated toad cornea. General Pharmacology 24: 867-872.

Norris, B., Quevedo, L. 1996. Adverse effects of polluted continental water bodies in Chile on frog adrenergic synapse. Bulletin of Environmental Contamination and Toxicology 57: 640-647.

Ortiz, J.C. 1988. Situación de la exportación de los vertebrados terrestres chilenos. Comunicaciones del Museo Regional de Concepción 2: 37-41.

Ortiz, J.L. 2002. Diseño de un sistema de calefacción para la rana grande chilena (Caudiverbera caudiverbera), en su estado larval. Undergraduate thesis. Universidad de Concepción, Chillán, Chile.

Otero, R., Jimenez-Huidobro, P., Soto-Acuña, S., YuryYáñez, E. 2014. Evidence of a giant helmeted frog (Australobatrachia, Calyptocephalellidae) from Eocene levels of the Magallanes Basin, southernmost Chile. Journal of South American Earth Sciences 55: 133-140.

Penna, M., Veloso, A. 1990. Vocal diversity in frogs of the South American temperate forest. Journal of Herpetology 24: 23-33.

Pratihar, S., Dutta, S.K., Bhattacharya, M, Clark, H. 2017. A mitogenomic exploration of the phylogeny and evolution of extant anurans. Russian Journal of Herpetology 24:
163-166.

Preller, A., Kessi, E., Ureta, T. 2007. Glycogen synthesis by the direct or indirect pathways depends on glucose availability: in vivo studies in frog oocytes. FEBS Letters 581: 663-666.

Puga, S. 1979. Gorgoderina valdiviensis sp. nov., un nuevo tremátodo digénico (Gorgoderidae) parasito de la rana chilena (Caudiverbera caudiverbera). Studies on Neotropical Fauna and Environment 14: 227-232.

Pyron, R.A. 2011. Divergence time estimation using fossils as terminal taxa and the origins of Lissamphibia. Systematic Biology 60: 466-481.

Pyron, R.A., Wiens, J.J. 2011. A large-scale phylogeny of Amphibia including over 2800 species, and a revised classification of extant frogs, salamanders, and caecilians. Molecular Phylogenetics and Evolution 61: 543-583.

Quiroz, D., Martínez, I. 2012. Restos de anfibios en la costa de la Araucanía: problematización y perspectivas. Revista Chilena de Antropología 29: 109-115.

Rabanal, F., Núñez, J. 2008. Anfibios de los bosques templados de Chile. Editions Universidad Austral de Chile, Valdivia. 203 pp.

Ramírez, D. 2018. Fauna Nativa de la Región de O’Higgins, Chile. Vertebrados Terresres. Editions Servicio Agrícola y Ganadero. 504 pp.

Romero, H., Molina, M., Moscoso, C., Sarricolea, P., Smith, P. 2007. Caracterización de los cambios de usos y coberturas de suelos causados por la expansión urbana de Santiago, análisis estadístico de sus factores explicativos e inferencias ambientales. In: Mattos, C., Hidalgo, R. (Eds) Santiago de Chile: movilidad espacial y reconfiguración metropolitana: 251-270. Pontificia Universidad Católica, Santiago, Chile.

SAG. 2020. La ley de caza y su reglamento. Servicio Agrícola y Ganadero, Santiago, Chile. 110 pp.

Sanhueza, M., Schmachtenberg, O., Bacigalupo, J. 2000. Excitation, inhibition, and suppression by odors in isolated toad and rat olfactory receptor neurons. American Journal of Physiology-Cell Physiology 279: C31-C39.

Schneider, C. 1930. Observaciones sobre batracios chilenos. Revista Chilena de Historia Natural 34: 220-223.

Soto-Azat, C., Peñafiel-Ricaurte, A., Price, S., Salaberry-Pincheira, N., García, M.P., Alvarado-Rybak, M., Cunningham, A. 2016. Xenopus laevis and emerging amphibian pathogens in Chile. EcoHealth 13: 775-783.

Suwalsky, M., Benites, M., Norris, B., Sotomayor, C.P. 2003. The organophosphorus insecticide chlorpyrifos affects the neuroepithelial junction, the bioelectric parameters of the skin of the frog Caudiverbera caudiverbera, and the structure of model cell membranes. Pesticide 
Biochemistry and Physiology 77: 44-53.

Suwalsky, M., Benites, M., Villena, F., Norris, B., Quevedo, L. 1998. The organochlorine herbicide chloridazon interacts with cell membranes. Comparative Biochemistry and Physiology Part C: Pharmacology, Toxicology and Endocrinology 120: 29-35.

Taibo, J.F. 2000. Comercialización de la carne de rana grande chilena (Caudiverbera caudiverbera). Undergraduate thesis. Universidad de las Américas, Santiago, Chile.

TNC. 2019. Plan de conservación humedal de Batuco 2018 2023. Fundación San Carlos de Maipo, Santiago, Chile. $148 \mathrm{pp}$.

Toledo, P.H., Suazo, R., Viana, M.T. 2014. Formulated diets for giant Chilean frog Calyptocephalella gayi tadpoles. Ciencia e Investigación Agraria 41: 13-20.

Tykot, R.H., Falabella, F., Planella, M.T, Aspillaga, E., Sanhueza, L., Becker, C. 2009. Stable isotopes and archaeology in central Chile: methodological insights and interpretative problems for dietary reconstruction. International Journal of Osteoarcheology 19: 156-170.

Vallejos, P., Pizarro, C. 2004. Crianza de la rana chilena Caudiverbera caudiverbera (Linnaeus, 1758), bajo sistema de cultivo semi extensivo. In: Iriarte, A., Tala, C., González, B., Zapata, B., González, G., Maino, M. (Eds.) Cría en cautividad de fauna chilena: 123-136. Servicio Agrícola y Ganadero, Parque Metropolitano and Facultad de Ciencias Veterinarias y Pecuarias de la Universidad de Chile.

Vélez, C.M., Acuña, P. L. 2012. Avances en el manejo ex situ de Calyptocephalella gayi (rana grande chilena). In: Soto-Azat, C., Valenzuela-Sánchez, A. (Eds.) Conservación de anfibios de Chile: 77-82. Universidad Andrés Bello, Santiago, Chile.

Vélez, C.M. 2014. Manejo en cautiverio de la rana grande chilena Calyptocephalella gayi (Duméril \& Bibron 1841). Editions
Universidad Santo Tomás, Santiago. 191 pp.

Veloso, A. 1977. Aggressive behavior and the generic relationships of Caudiverbera caudiverbera (Amphibia: Leptodactylidae). Herpetologica 33: 434-442.

Venegas, W., Hermosilla, I., Quevedo, L., Montoya, G. 1993. Genotoxic and teratogenic effect of pentachlorophenol, pollutant present in continental water bodies in the South of Chile. Bulletin of Environmental Contamination and Toxicology 51:107-114.

Vera Candioti, M.F., Altig, R. 2010. A survey of shape variation in keratinized labial teeth of anuran larvae as related to phylogeny and ecology. Biological Journal of the Linnean Society 101: 609-625.

Vietmeyer, N. 1985. Underexploited plant and animal resources for developing country agricultura. In: Elfring, C. (Eds.) OTA workshop staff on innovative biological technologies for lesser developed countries: 37-48. National Academy of Sciences Washington, USA.

Villagrán, C., Villa, R., Hinojosa, L., Sánchez, G., Romo, M., Maldonado, A., Cavieres, L., Latorre, C., Cuevas, J., Castro, S., Papic, C., Valenzuela, A. 1999. Etnozoología mapuche: Un estudio preliminar. Revista Chilena de Historia Natural 72: 595-627.

Voyles, J., Young, S., Berger, L., Campbell, C., Voyles, W., Dinudom, A., Cook, D., Webb, R., Alford, R., Skerratt, L. 2009. Pathogenesis of chytridiomycosis, a cause of catastrophic amphibian declines. Science 326: 582-585.

Wilhelm, O., Lazcano de Vivaldi, E. 1958. El órgano de Bidder en Calyptocephalus gayi (primera nota preliminar). Boletín de la Sociedad de Biología de Concepción 33: 21-27.

Wolffhugel, K. 1948. Ophiotaenia noei n. sp. (Cestoda). Biológica 5: $15-27$.

WWF 2014. Living planet report 2014: species and spaces, people and places. WWF, London.

Received: 19.07.2020

Accepted: 17.03.2021 